\title{
Pembuatan Material Sensor Kelembaban Relatif Berbasis Film Polianilin-Selulosa Ampas Tebu
}

\author{
Anggi*, Afdhal Muttaqin \\ Jurusan Fisika FMIPA Universitas Andalas \\ Kampus Unand, Limau Manis, Padang 25163 \\ *anggidoank2131@gmail.com
}

\begin{abstract}
ABSTRAK
Telah dilakukan pembuatan material sensor kelembaban relatif berbasis film polianilin-selulosa ampas tebu. Sintesis selulosa ampas tebu dilakukan menggunakan metode hidrolisis dengan penambahan $\mathrm{NaOH}$ 17,5\% dan $\mathrm{HCl}$ 0,1 M. Pembuatan PANi-selulosa menggunakan $10 \mathrm{ml}$ anilin dengan variasi selulosa $0,50 \mathrm{~g}, 1,00 \mathrm{~g}$ dan 1,50 g. PANi-selulosa yang dihasilkan dikarakterisasi menggunakan FTIR. Film PANiselulosa dibuat dengan metode dip coating selama 10 menit. Pengukuran resistansi film PANi-selulosa terhadap perubahan kelembaban relatif menggunakan ohmmeter dilakukan dalam chamber. Hasil karakterisasi FTIR menunjukkan penambahan selulosa menghasilkan ikatan amina, alkana, alkena yang lebih banyak. Sintesis selulosa menghasilkan selulosa sebanyak 12,71 g dari 50,00 g ampas tebu. Material sensor kelembaban relatif yang dibuat dari bahan PANi-selulosa ampas tebu dapat bekerja pada kelembaban relatif 32,65 - 93,10\%. Pengukuran resistansi menunjukkan penambahan selulosa dan peningkatan kelembaban relatif akan memperkecil nilai resistansi. Linearitas sensor yang tertinggi didapatkan pada sampel dengan penambahan selulosa $1,00 \mathrm{~g}$ dengan $\mathrm{R}^{2}=0,932$. Uji durabilitas selama 18 hari menunjukkan nilai resistansi naik terutama pada kelembaban relatif di atas 75,51\%. Durabilitas tertinggi diperoleh pada sampel dengan penambahan selulosa $0,50 \mathrm{~g}$.

Kata kunci : polianilin, selulosa ampas tebu, sensor kelembaban
\end{abstract}

\begin{abstract}
Fabrication of relative humidity sensor material polyaniline-based bagasse cellulose film has been done. synthesis of bagasse cellulose with hydrolisis method with the addition of $17.5 \% \mathrm{NaOH}$ and $0.1 \mathrm{M} \mathrm{HCl}$. Fabrication of PANi-cellulose using $10 \mathrm{ml}$ of aniline with variations of cellulose $0.50 \mathrm{~g}, 1.00 \mathrm{~g}$ and $1.50 \mathrm{~g}$. PANi-cellulose products were characterized using FTIR. PANi-cellulose films was made with dip coating method for 10 minutes. Resistance measurement of PANi-cellulose to the changes in relative humidity using ohmmeter was performed in the chamber. FTIR characterization results indicate the addition of cellulose produced more amine, alkane, alkene bonds. Cellulose synthesis produced $12.71 \mathrm{~g}$ cellulose from $50.00 \mathrm{~g}$ bagasse. Relative humidity sensor material that was made from PANi-cellulose bagasse materials work well at a relative humidity from 32.65 - $93.10 \%$. Resistance measurement shows the addition of cellulose and the increase of relative humidity will reduce the resistance value. Highest sensor linearity is found in the sample with the addition of $1.00 \mathrm{~g}$ cellulose $R^{2}=0.932$. Durability test during 18 days show increasing resistance value, especially at a relative humidity above 75.09\%. The highest durability is obtained on the sample with the addition of $0.50 \mathrm{~g}$ cellulose.

Keywords : polyaniline, bagasse cellulose, sensor humidity
\end{abstract}

\section{PENDAHULUAN}

Kelembaban adalah banyaknya kadar atau uap air yang terkandung di udara. Ada beberapa jenis kelembaban yaitu kelembaban absolut, kelembaban rasio, kelembaban relatif dan kelembaban spesifik. Kelembaban relatif adalah perbandingan kandungan kelembaban udara dengan tingkat kelembaban saturasi pada temperatur dan tekanan yang sama.

Dalam sistem instrumentasi elektronika, sensor kelembaban merupakan instrumen yang mengubah banyaknya uap air yang teradsorpsi pada bahan pengindera menjadi besaran listrik, dimana jumlah uap air menunjukkan besarnya kelembaban relatif di udara. Besaran listrik yang biasanya digunakan pada sensor kelembaban ialah resistansi (sensor kelembaban jenis resistif) dan kapasitansi (sensor kelembaban jenis kapasitif) (Denton dkk., 1985).

Penelitian tentang bahan-bahan yang dapat digunakan sebagai sensor kelembaban telah berkembang pesat. Beberapa jenis bahan seperti keramik (Bearzotti, dkk., 1994) dan polimer (Gunawan, 2012) telah diteliti dan diuji untuk dimanfaatkan sebagai bahan sensor kelembaban. Perkembangan ini didasarkan pada hipotesis bahwa setiap jenis bahan, seperti polimer atau keramik memiliki sifat listrik (dielektrik dan konduktivitas) tertentu, bila bahan-bahan tersebut menyerap uap air maka terjadi perubahan sifat kelistrikan bahan (Denton dkk., 1985). Apabila 
jumlah uap air yang terserap pada bahan sebanding dengan perubahan sifat listriknya maka bahan tersebut berpotensi untuk digunakan sebagai bahan sensor kelembaban (Yamazoe dan Shimizu, 1986).

Pembuatan sensor kelembaban banyak dibuat dari polimer konduktif karena proses preparasi dan fabrikasinya yang relatif lebih sederhana sehingga terciptanya suatu sensor yang murah. Pengembangan material yang dapat digunakan sebagai sensor kelembaban didasari pada nilai ekonomis, mudah diproduksi, tahan korosi, memiliki sensitivitas yang baik dan dapat didaur ulang (Chen dan Lu, 2005).

Salah satu contoh polimer konduktif adalah polianilin (PANi). PANi memiliki konduktivitas yang tinggi, stabilitas lingkungan yang baik dan mudah disintesis (Li dkk., 2010). PANi masih memilki kelemahan yaitu sifat fisik yang kaku sehingga dapat membatasi penggunanya. Beberapa penelitian menyatakan bahwa kekakuan tersebut dapat diatasi dengan pembentukan komposit. Selain itu, pembentukan komposit tersebut juga dapat meningkatkan nilai konduktivitas (Feng dkk., 2003). Feng, dkk., (2003) mendapatkan bahwa nilai konduktivitas komposit polianilin-karbon yaitu $10^{0}-10^{1} \mathrm{~S} / \mathrm{cm}$ dan nilai ini lebih tinggi jika dibandingkan dengan nilai konduktivitas murni yang berkisar antara $10^{-2}-10^{-1} \mathrm{~S} / \mathrm{cm}$. Konduktivitas polimer dapat ditingkatkan dengan penambahan matrik. Matrik yang biasa digunakan dalam pembuatan komposit ialah plastik, karet dan selulosa.

Selulosa merupakan salah satu bahan yang digunakan sebagai matrik dalam proses pembuatan komposit PANi karena sifatnya yang fleksibel. Sumber selulosa yang digunakan pada penelitian ini berasal dari ampas tebu yang telah diekstrak. Pemilihan ampas tebu sebagai sumber selulosa dikarenakan keberadaanya yang melimpah serta kandungan selulosanya yang relatif tinggi. Ampas tebu merupakan sisa bagian batang tebu dalam proses ekstraksi tebu yang masih memiliki kadar air, serat dan padatan terlarut. Pada prinsipnya serat ampas tebu terdiri dari selulosa, pentosan dan lignin. Komposisi ketiga komponen bisa bervariasi pada varitas tebu yang berbeda.

Penelitian ini bertujuan membuat material sensor kelembaban relatif dari PANi-selulosa ampas tebu, mengkarakterisasi PANi-selulosa menggunakan FTIR untuk melihat struktur ikatan yang terbentuk, melakukan pengukuran resistansi terhadap perubahan kelembaban relatif dan mengukur durabilitas sensor.

\section{METODE}

Ampas tebu dipotong-potong $\pm 1 \mathrm{~cm}$, kemudian dicuci menggunakan aquades. Ampas tebu yang sudah bersih kemudian dijemur di bawah sinar matahari hingga kering dan di oven selama 12 jam. Selanjutnya ampas tebu digiling hingga halus. Ampas tebu yang halus dikeringkan kembali dalam oven pada temperatur $100{ }^{\circ} \mathrm{C}$ selama 2 jam.

Ampas tebu yang telah halus ditimbang sebanyak 50,00 g dan dimasukkan ke dalam gelas piala $1000 \mathrm{ml}$. Selanjutnya ditambahkan $\mathrm{NaOH}$ 17,5\% dan ditambahkan aquades hingga mencapai $500 \mathrm{ml}$, diaduk dan dipanaskan pada temperatur $80{ }^{\circ} \mathrm{C}$ selama 4 jam menggunakan hot plate magnetic stirrer. Hasil leburan disaring dan endapan dicuci menggunakan aquades. Residu yang dihasilkan dihidrolisis menggunakan $\mathrm{HCl}$ 0,1 M sebanyak $100 \mathrm{ml}$ dan dipanaskan pada temperatur $70{ }^{\circ} \mathrm{C}$ selama 1 jam menggunakan hot plate magnetic stirrer dan selanjutnya dicuci dengan aquades dan etanol $96 \%$. Selulosa hasil sintesis dikeringkan dalam oven pada temperatur $105^{\circ} \mathrm{C}$ selama 6 jam.

Selulosa dengan variasi berat yaitu $0,50 \mathrm{~g}, 1,00 \mathrm{~g}$ dan $1,50 \mathrm{~g}$ dicampurkan ke dalam 10 $\mathrm{ml}$ anilin. Kemudian campuran ini dilarutkan dalam $200 \mathrm{ml} \mathrm{HCl} 2 \%$ dan diaduk dengan hot plate magnetic stirrer selama $1 \mathrm{jam}$. Selama proses pengadukan $5 \mathrm{ml}$ larutan $\mathrm{CuSO}_{4} \cdot 5 \mathrm{H}_{2} \mathrm{O} 1 \mathrm{M}$ ditambahkan ke dalam campuran dengan cara diteteskan. Hasil pengadukan disaring menggunakan kertas saring sehingga hanya menyisakan residu coklat. PANi-selulosa yang didapatkan dikeringkan pada temperatur $50^{\circ} \mathrm{C}$ dalam oven selama 24 jam.

PANi-selulosa hasil sintesis ditambahkan $25 \mathrm{ml}$ aquades kemudian di-coating di atas papan PCB dengan metode dip coating dengan waktu celup selama 10 menit. Film PANi selulosa yang terbentuk pada papan PCB di-aging selama 24 jam pada temperatur kamar. Pengukuran resistansi terhadap kelembaban relatif dilakukan pada suatu ruangan terisolasi yang di dalamnya terdapat bejana larutan garam. Sensor PANi-selulosa dirangkai dengan kabel 108 
penghubung yang disambungkan pada ohmmeter. Pada pengukuran resistansi, kelembaban relatif yang diperoleh tidak mengukur temperatur di dalam chamber sehingga kelembaban relatif yang diperoleh berdasarkan rentang temperatur $25-30{ }^{\circ} \mathrm{C}$. Rentang temperatur yang digunakan tidak terlalu mempengaruhi kelembaban relatif karena perbedaan nilainya kurang dari $1 \%$.

\section{HASIL DAN DISKUSI}

\subsection{Sintesis Selulosa Ampas Tebu}

Pada sintesis selulosa ampas tebu, massa tepung ampas tebu yang digunakan sebanyak 50,00 g. Setelah dilakukan proses hidrolisis dengan $\mathrm{NaOH}$ 17,5\% dan $\mathrm{HCl} \mathrm{0,1} \mathrm{M} \mathrm{didapatkan}$ hasil sintesis sebanyak $12,71 \mathrm{~g}$ selulosa atau $25,42 \%$. Hasil ini jika dibandingkan dengan ubi gajah dan tanah gambut selulosa yang diperoleh dari ampas tebu lebih banyak. Mandela (2016) menyintesis selulosa dari ubi gajah menghasilkan sebanyak 2,6 g selulosa atau 5,2\%, dan Abus dkk. (2013) menyintesis selulosa dari tanah gambut diperoleh selulosa sebanyak $6 \mathrm{~g}$ atau $12 \%$.

\subsection{Sintesis Polianilin-selulosa}

Proses polimerisasi dibagi ke dalam tiga tahapan yaitu, inisiasi, propagasi dan terminasi. Ketiga tahapan tersebut dapat diamati melalui perubahan temperatur dan waktu pada saat polimerisasi berlangsung. Perubahan saat polimerisasi anilin pada penelitian ini dapat dilihat seperti pada Gambar 1. Berdasarkan hasil polimerisasi, secara fisik dapat diamati perubahan warna anilin. Larutan anilin yang semula berwarna jingga secara bertahap berubah menjadi hijau kemudian coklat.
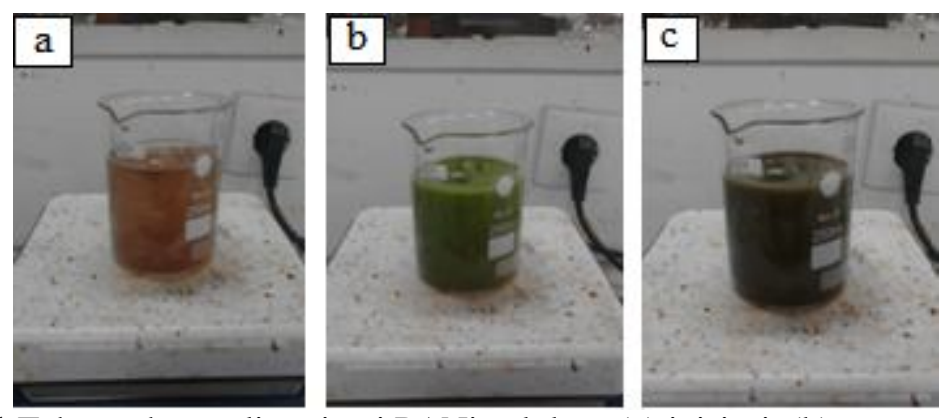

Gambar 1 Tahap-tahap polimerisasi PANi-selulosa (a) inisiasi, (b) propagasi, dan (c) terminasi

\subsection{Karakterisasi FTIR}

PANi-selulosa yang dihasilkan dianalisis menggunakan FTIR untuk membuktikan terjadinya pencangkokkan, dengan melihat puncak-puncak serapan yang muncul. Dari puncak serapan yang dihasilkan, dapat dilihat bahwa puncak serapan pada masing-masing penambahan selulosa tidak terlalu berbeda.

Puncak-puncak serapan yang dihasilkan pada Gambar 2 (a) diperoleh transmitansinya lebih besar dibandingkan dengan penambahan selulosa lainnya. Selain itu penambahan selulosa 0,50 g menghasilkan sedikit gugus fungsi amina, alkana dan alkena yang mengindikasikan bahwa proses pencangkokkan belum terjadi secara maksimal.

Penambahan selulosa mampu menghasilkan puncak-puncak baru dengan transmitansi yang lebih kecil. Hal ini dapat dilihat pada Gambar 2 (b) dan (c) yang merupakan kurva penambahan selulosa 1,00 g dan 1,50 g. Pada kedua sampel terdapat ikatan amina, alkana dan alkena dihasilkan lebih banyak dibandingkan dengan selulosa $0,50 \mathrm{~g}$, ini menunjukkan bahwa penambahan selulosa dapat menghasilkan transmitansi yang lebih kecil dan ikatan yang lebih banyak.

Posisi puncak-puncak yang termati dalam Gambar 2 merupakan gugus yang ada di dalam PANi dan selulosa. Pada PANi-selulosa terlihat adanya serapan yang muncul pada puncak serapan gugus $(\mathrm{C}-\mathrm{H})$, ikatan rangkap $(\mathrm{C}=\mathrm{H})$. Puncak serapan yang menandakan adanya ikatan $(\mathrm{C}-\mathrm{N})$ dan $(\mathrm{C}=\mathrm{C})$. Puncak serapan yang menandakan adanya gugus $(\mathrm{O}-\mathrm{H})$ dan $(\mathrm{N}-\mathrm{H})$ 
yang mana dari ikatan-ikatan tersebut merupakan struktur ikatan yang ada dari PANi dan selulosa. Hal ini mengindikasikan bahwa telah terjadi pencangkokkan antara PANi dengan selulosa.
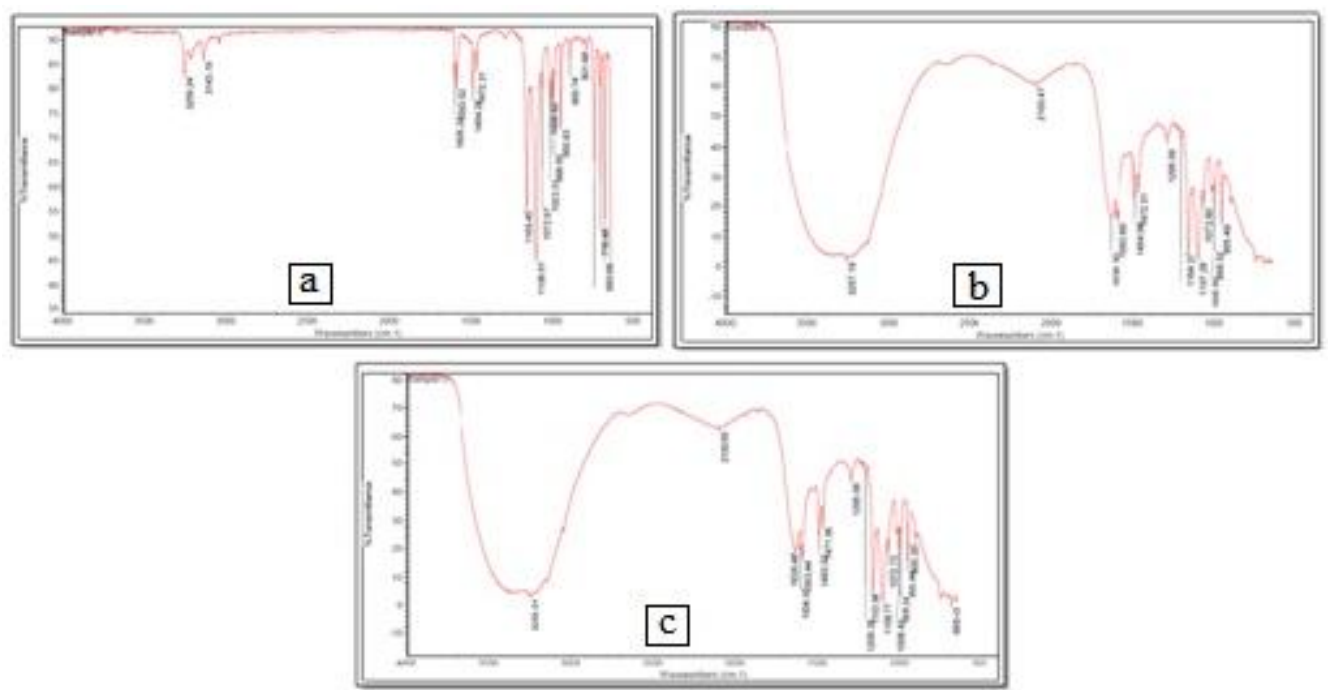

Gambar 2 Puncak serapan PANi-selulosa (a) penambahan selulosa 0,50 g, (b) penambahan selulosa $1,00 \mathrm{~g}$, dan (c) penambahan selulosa $1,50 \mathrm{~g}$

\subsection{Resistansi PANi-Selulosa}

Pengukuran resistansi dilakukan menggunakan ohmmeter. Resistansi yang diukur diperoleh dari perubahan kelembaban relatif menggunakan larutan garam jenuh. Film PANiselulosa diukur resistansinya pada hari ke-1, ke-10 dan ke-18. Tujuan dari dilakukannya pengukuran resistansi tersebut, selain untuk melihat pengaruh resistansinya juga untuk melihat durabilitas sensor.



Gambar 3 Grafik hubungan resistansi terhadap kelembaban relatif hari ke 1

Dari Gambar 3 dapat dilihat koefisien determinasi $\left(\mathrm{R}^{2}\right)$ dari penambahan selulosa $0,50 \mathrm{~g}, 1,00 \mathrm{~g}$ dan $1,50 \mathrm{~g}$ berturut-turut sebesar 0,890, 0,932 dan 0,917. Nilai linearitas yang lebih baik yaitu sebesar 0,932 diperoleh pada penambahan selulosa 1,00 g. Sensitivitas ditunjukkan dengan perbandingan nilai resistansi terhadap kelembaban relatif. Pada penambahan selulosa $1,00 \mathrm{~g}$ sensitivitasnya $-0,426 \mathrm{M} \Omega / \%$, ini menunjukkan bahwa setiap kenaikkan kelembaban relatif $1 \%$ akan mengakibatkan penurunan resistansi sebesar 0,426 $\mathrm{M} \Omega / \%$. 
Dari Gambar 3 terlihat bahwa resistansi yang terukur semakin menurun bila kondisi kelembaban relatif dalam chamber ditingkatkan dari 32,44\% sampai dengan 93,58\%. Perbedaan dari ketiga sampel hanya pada besarnya nilai resistansi. Pada penambahan selulosa sebanyak 0,50 g resistansinya dimulai dari 51,93 - 14,65 M 2 . Pada sampel dengan selulosa $1,00 \mathrm{~g}$ resistansinya $39,11-10,86 \mathrm{M} \Omega$ dan terakhir pada penambahan selulosa $1,50 \mathrm{~g}$ resistansi yang diperoleh 31,02 - 8,75 M . Dapat dilihat dari ketiga data yang diperoleh, perubahan resistansi menurun tetapi nilainya yang berbeda.

Dari Gambar 3 menunjukkan bahwa resistansi yang dihasilkan semakin kecil jika penambahan selulosa semakin banyak. Hasil ini didukung oleh karakterisasi FTIR yang menunjukkan pada sampel dengan penambahan selulosa $1,00 \mathrm{~g}$ dan 1,50 g pencangkokkan PANI-selulosa menghasilkan ikatan amina, alkana dan alkena yang semakin banyak, maka rantai polimer yang dihasilkan semakin panjang. Apabila semakin panjang rantai polimer, maka matrik pengikat filler juga semakin banyak. Dalam aplikasi sensor kelembaban, filler film polimer berfungsi sebagai molekul air. Semakin banyak ion pengantar muatan sehingga resistansi bahan semakin kecil. Hasil ini sesuai dengan penelitian Shukla (2012) yang menunjukkan bahwa apabila kelembaban relatif dinaikkan maka resistansi turun.

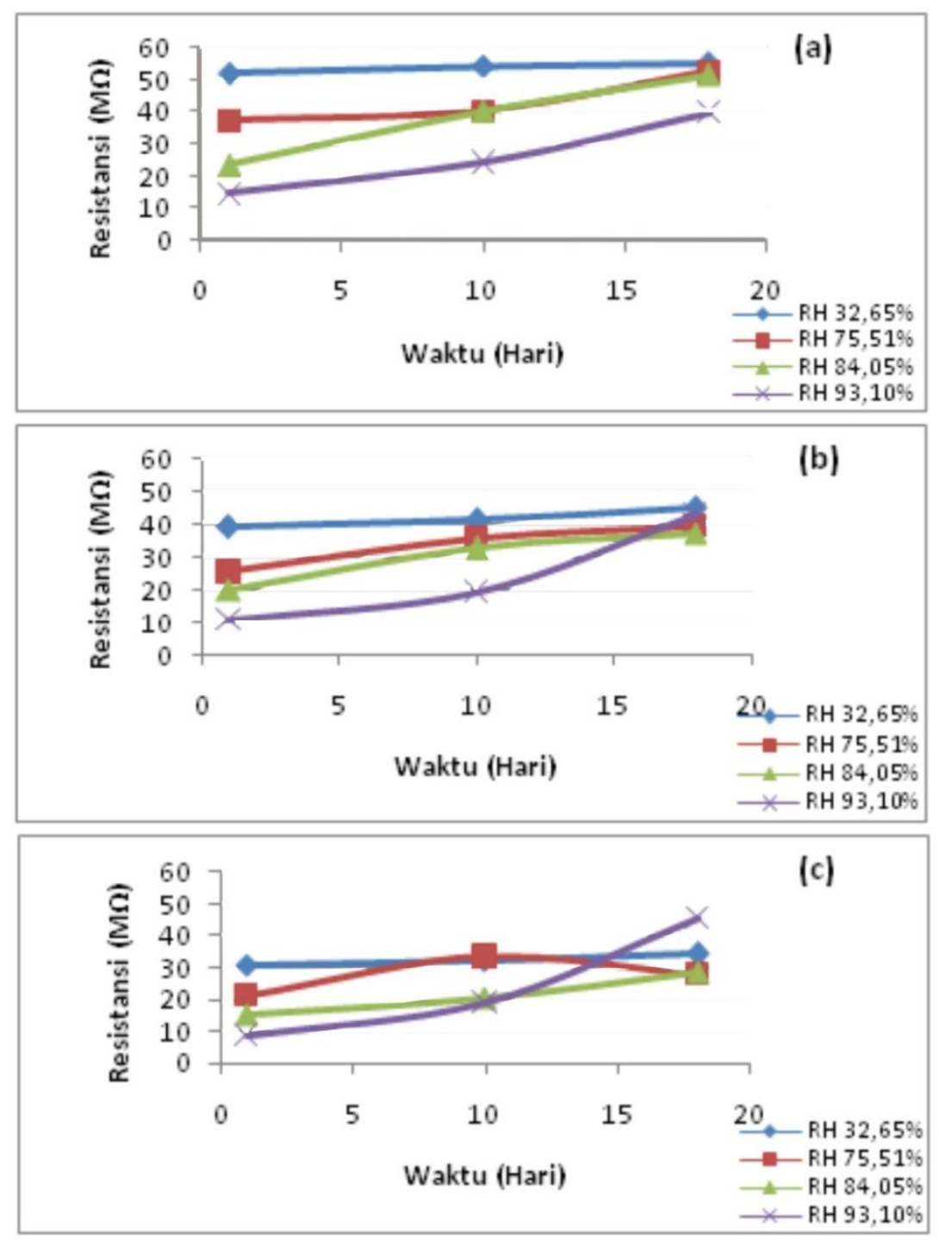

Gambar 4 Grafik resistansi terhadap waktu untuk RH yang berbeda-beda (a) penambahan selulosa 0,50 g, (b) penambahan selulosa 1,00 g, dan (c) penambahan selulosa 1,50 g

Selain itu, resistansi dari film PANi-selulosa disebabkan oleh ion $\mathrm{H}^{+}$yang berasal dari $\mathrm{H}_{2} \mathrm{O}$ yang teradsorbsi dan terionisasi. Semakin tinggi kelembaban relatif kadar air semakin 
meningkat, sehingga jumlah ion $\mathrm{H}^{+}$semakin banyak. Dengan demikian resistansi film menjadi rendah.

Dari Gambar 4 terlihat bahwa pada kondisi kelembaban relatif yang rendah yaitu sebesar 32,65\% tidak dijumpai perubahan resistansi yang signifikan, sedangkan pada kelembaban relatif $75,51 \%$ atau yang lebih tinggi, nilai resistansi naik terhadap waktu. Hal ini menunjukkan penurunan sensitivitas sensor berkurang seiring pemakaian sensor. Penurunan sensitivitas sensor ini juga disebabkan oleh proses peng-aging-an. Dari Gambar 4 dapat juga dilihat pada penambahan selulosa $0,50 \mathrm{~g}$ perubahan resistansi lebih stabil dibandingkan dengan penambahan selulosa lainnya. Ini dapat diartikan durabilitas sensor yang baik pada sampel dengan penambahan selulosa $0,50 \mathrm{~g}$.

\section{KESIMPULAN}

Sintesis selulosa dari ampas tebu dengan penambahan $\mathrm{NaOH}$ 17,5 \% dan $\mathrm{HCl} 0,1 \mathrm{M}$ menghasilkan selulosa sebanyak 12,71 g dari 50,00 g ampas tebu. Material sensor kelembaban relatif yang dibuat dari bahan PANi-selulosa ampas tebu dapat bekerja pada kelembaban relatif $32,44-92,08 \%$. Penambahan selulosa pada proses pencangkokkan menghasilkan ikatan amina, alkana dan alkena yang lebih banyak dan pengukuran menunjukkan resistansi semakin kecil. Resistansi terlihat menurun jika kelembaban relatif ditingkatkan. Linearitas sensor yang tertinggi didapatkan pada sampel penambahan selulosa $1,00 \mathrm{~g}$ dengan $\mathrm{R}^{2}=0,932$. Pada pengujian durabilitas sensor selama 18 hari diketahui nilai resistansi naik terutama pada kelembaban relatif di atas $75,51 \%$. Durabilitas tertinggi dihasilkan pada sampel dengan penambahan selulosa $0,50 \mathrm{~g}$.

\section{DAFTAR PUSTAKA}

Abus, P., Rudiyansyah, dan Sitorus, B., JKK, Vol 2 (2), (2013),

Bearzotti, A., Bianco, A., Monstesperelli, G., dan Traversa, E., Sensors and Actuators B, (1994), hal. 525-528.

Chen, Z. dan Lu, C., Humudity Sensor : A Review of Material and Mechanism, Sensor Letters, hal. 274-295 (2005).

Denton, D.D., Senturia, S.D., Anolick E.S. dan Scheider, D.,"Fundamental Isues in The Design of Polymeric Capacitive Moisture Sensors, Digest of Technical Papers", $3^{\text {rd }}$ Int. Conf. On Solidstate Sensor and Actuators (Transducer '85), (Philadelphia, 1985)

Feng, W., Bai, X.D., Lian, Y.Q., Liang, J., Wang, X.G. dan Yoshino, K., Carbon, Vol. 41, Issue 8, (2003), hal. 1551-1557.

Gunawan, B.,"Uji Pengaruh Suhu dan Kelembaban Terhadap Nilai Resistansi Chemical Sensor Based Polymer dengan Metode Pengujian Injeksi Dalam Chamber Terisolasi. The $6^{\text {th }}$ Electrical Power, Electronics, Communications, Controls, Informatics International Seminar, (Universitas Brawijaya, Malang, 2012).

Li, Jian, Xueren, Q., Wang, L. dan An, X.H., J. Bio. Tech., Vol. 5 (2010), hal.712-726.

Mandela, R,"Pembuatan Sensor Kelembaban Relatif Berbasis Selulosa Umbi Gajah dan Polianilin", Skripsi S1, Universitas Andalas, 2016.

Shukla, K,S., Indian Journal of Engineering \& Materials Sciences, Vol. 19 (2012), hal 417-420.

Wulandari, D., Imawan, C. dan Sabarinah, Y.,"Preparasi dan Karakterisasi Film Komposit $\mathrm{PVA}_{-\mathrm{TiO}}$ Sebagai Sensor Kelembaban”. Prosiding Simposium Nasional Polimer V, (Jakarta, 2010).

Yamazoe, N. dan Shimizu, Y., Sensor and Actuators, Vol. 10 (1986), hal. 379 - 398. 